\title{
Death Gets Personal: Inventing Early Modern Grief in 15th Century Spain
}

\author{
Samuel Sánchez y Sánchez \\ Davidson College
}

Charged with an unusual poetic force, Act XXI of Celestina by Fernando de Rojas presents an enactment of paternal pain in which Pleberio laments his daughter's self-inflicted death. More than other passages in Rojas' work, Act XXI proves to be an inexhaustible source of illuminating and often conflicting readings as the abundant amount of scholarly attention that this episode has generated over the years illustrates. ${ }^{1}$ Driven by a more interdisciplinary spirit that reflects the increasing permeability of the divisions between academic disciplines and fields ${ }^{2}$ late medievalists

1.- Over the years hispanomedievalists have continued to reexamine Pleberio's lament focusing on two opposing perspectives regarding the relationship between Rojas and Pleberio. Some critics, such as Stephen Gilman and Bruce Wardropper, believe that Rojas is filtering his own ideas and thoughts through Pleberio's words with the intent to achieve moralistic universal implications. On the contrary, Marcel Bataillon, Peter Dunn, Erna Berndt, and Otis Green, among others, refuse to accept Pleberio as the author's mouthpiece, and defend the thesis that Pleberio's soliloquy cannot be interpreted as an expression of cosmic despair. For her part, María Rosa Lida de Malkiel's La originalidad artística de "La Celestina» meets both approaches half way by reconciling Pleberio's individuality as a character and his role as the spokesman of Rojas' world view. Another major current in Celestina criticism focuses on the study of this lament as a structural and thematic unity within the rest of the novel. In this sense, the varying interpretations of Act XXI have ranged from those classifying Pleberio's soliloquy as «a thematic epilogue» (e.g. Gilman), a summation illuminating the overall meaning of the work (e.g. María Rosa Lida de Malkiel), a personal commentary (e.g. Erna Ruth Berndt), a "genuine summing up» that "cannot not be dismissed as tasteless appendage» (e.g. Charles Fraker), and a contradictory ending of the work (e.g. Bataillon). Additionally, Act XXI has naturally been studied against the background of medieval mourning and the elegiac literary tradition that pervades 15 th Century Spain. The most influential works in this area will be mentioned in the course of the present article.

2.- For a sample of this scholarly trend see the collection of essays edited by Stephen Greenblatt and Giles Gunn under the title of Redrawing the Boundaries: The Transformation of English and American Literary Studies (Modern Language Association, 1992), especially Anne Middleton's essay on medieval Studies, and Leah Marcus' piece on Renaissance and early modern 
and early modernists are presently posing a new set of questions to $\mathrm{Ce}$ lestina. The methodological perspectives provided by gender studies, anthropology, feminist studies, and cultural studies, among others, examine Rojas' work as an example of "socially responsive literature; that is, the kind of literature that, as Julio Rodríguez Puértolas reminds us, «must sink its roots in the collective consciousness of a period, or reflect its collective unconscious» (1968: 12). This turn to interdisciplinarity in Celestina studies gives voice to readings silenced by the very text because, as Paul Strohm notes, "a text cannot fully reveal itself, unless pressured by questions formed somewhere outside its own orbit of assumptions» (2000: xxii). One text and a multidisciplinary approach: two equally necessary aspects to illuminate the «textual consciousness» of a work - Celestina-, and a passage - Act XXI- that, as the copious amount of criticism indicates, resists closure.

In this light, this essay examines Pleberio's lament for Melibea from a perspective in which the literary representation of grieving meets social practices of mourning and converges with the emergence of individuality on the cusp of the Spanish Renaissance. My reading of this lament reflects upon how early modern grief, as conceived by Rojas, initiates a personalized narrative of substitution that entails an apparent paradox: the deceased serves as the catalyst that triggers this response, and yet is displaced as protagonist in favor of the survivor who becomes the center of this exposition of grief. ${ }^{3}$

In the context of Pleberio's lament, this essay explores the tension between the need to memorialize the deceased and a self-serving attitude towards the dead. Pleberio's verbal response to his loss constitutes an early modern narrative that evolves from the customary third person account focused on the deceased to a personal "life-story» centered on the living, thus reflecting a shift from collective to individualized responses to death. The emphasis on the living «I» rather than the deceased «she» in this narrative illustrates how an early modern author makes sense of death by proposing a self-centered model of grief which, focusing on the survivor, allows him to negotiate personal identity in the face of the very experience that erases it. As a consequence, within the context of an inverted memento mori -in this particular case the death of the other prompts mediation upon one's own life rather than one's death- grief, I argue, becomes a culturally bound concept charged with an instrumental value at this historical moment of emerging individualism. The examination of this literary expression of grieving as a signifying process uncovers

studies. See also Renaissance Quarterly (Volume LXII, No. 1 Spring 2009) as a good example of the questioning of boundaries among academic disciplines.

3.- In terms of Pleberio's expression of personal grief, Michael Gerli points out that this character «is the traditional expositor suddenly endowed with a profound sense of self-awareness» (1976: 69). 
a particularly early modern attitude towards loss. Here grief is viewed as a goal-oriented and self-serving process that not only challenges generic manifestations of mourning but also reveals a new shift in the process of expressing pain: a turn that invokes the metamorphosis of medieval pain into early modern suffering by reformulating the traditional relationship among the bereaved, loneliness, and language.

\section{Discovering Individual Grief: From Medieval Pain to Early Modern Suffering}

Death happens to everyone. We live with the paradoxical truth that one day we will die and yet with the tragic experience that while we live, "everyone» is always the other. Death is inherently a shared experience - the great common denominator- yet we necessarily spend our existence as survivors of the death of others, as story-tellers of narratives, as guarantors of the delicate balance between presence and absence, memory and forgetfulness, pain and relief, voice and silence. These are some of the elements that make of mourning the death of a loved one a universal human emotion. As studies have shown, mourning is a complex process comprised of several elements that remain constant across cultures - crying, fear, anger, and guilt, for example - and others that are particular to certain cultures. Mourning refers, then, to the grief-infused symbolic actions that give shape to culturally-constructed responses to loss (Homans 2000: 2-3). Grief is an emotion triggered by loss that encompasses common thoughts and feelings that range from disbelief, confusion, anxiety tension, or pain to sadness, longing, loneliness, sorrow, guilt, and anger, among others. ${ }^{4}$

Literary representations of grief in medieval Spain certainly reflect these feelings. Spanish medieval authors were, of course, aware of the literary potential of such an emotionally charged figure as the mourner but they did not, however, develop them as individual characters at this particular emotional juncture. Medieval Spain seemed to have no room for individuality in death for either the deceased or the survivor. The expression of the feelings of the dying was circumscribed to the model imposed by the Ars Moriendi. ${ }^{5}$ Under the long didactic shadow of this text, the medi-

4.- In the course of this essay I am using the term 'grief' to refer to the psychological reaction to bereavement and the term 'mourning' for the public display of this emotion. Together they give shape to the way in which an individual integrates the loss of a loved one into his or her life as way for coping with bereavement. I am approaching 'grief' in particular as a concept to be included sin a cultural plot whereby individual identity is the privileged site of a meaning setting itself against incursive or radically exterior aspects of reality» (Spargo 2004: 93).

5.- The generic title of Ars Moriendi refers to two works in the 15th century which, despite being structurally and thematically similar, differ in textual variants, derivations and length. 
eval literary representation of death emphasized the role of the dying but rarely focused on the survivor. The expression of grief for the survivors was subjugated to a collective formula in the form of the literary lament. Erasing any trace of individuality, this literary genre imposed strict rules of form and content that created a rigid narrative model of grief centered on the deceased with little attention given to survivors. ${ }^{6}$ In this way, the community had devised the patterns of collective expression for two individual moments that converged in the deceased: the moment of dying and the expression of grief. The medieval narrative of grief focuses on the dearly departed and prevents the emergence of a truly individual expression on part of the survivor. This literary model for the enactment of grief relies, then, on a concept of mourning viewed as a common experience with distinct stages characterized by predictable patterns of behavior accompanied by socially determined modes for channelling the expression of grief, where the protagonist is the deceased.

Whereas the universal and cultural aspects of grief define the Spanish literary response to death in the Middle Ages, with the dawn of modernity the representation of grieving emerges as space for the interrogation of bereaved's identity by means of a personalized response to loss, a re-

The longest version, supposedly written between 1414 and 1418 by an anonymous Dominican monk, was transmitted mainly via manuscript and is commonly called Tractatus, or Speculum, artis bene moriendi. This text is divided into six parts: (1) a general introduction to the science of dying well; (2) a discussion of how to overcome the five temptations that the devil uses to assault moriens: doubt against faith, desperation, impatience, vainglory and greed; (3) a series of questions that guaranteed moriens' salvation if answered correctly; (4) Rules prescribing the way moriens must act at this critical juncture; (5) Instructions to those who accompany moriens on how they are supposed to act; and (6) a series of prayers that must be recited for moriens' salvation. The shorter text was transmitted in xylographic editions and is known as Ars Moriendi. Its anonymous author borrows elements from the long version and transforms the text into a theatrical debate in which the devil tempts moriens while an angel encourages him to resist. (Gago 1999: 28-34). See: Francisco Gago Jover, ed. (1999), Arte de bien morir y breve confesionario (Zaragoza, Pablo Hurus: 1479-1484). Palma de Mallorca, Universitat de les Illes Balears, Servei de Publicacions.

6.- In fact, the lament followed a model admitting no improvisation: to begin, there were curses against death, followed by a description of death as the great equalizer, as an inevitable, sudden, and arbitrary event, of the physical and moral corruption brought by death upon the deceased and survivors, then of biblical characters exemplifying a good death, Jesus Christ as salvation, and finally a lament for the dead which included a prayer for the soul of the deceased and praise of his or her good qualities. This is exactly what we find, for example, in Juan Ruiz's lament for Trotaconventos in Libro de buen amor: the initial rage of the archpriest, his tension, and sadness vanish as the narrative that he has crafted as a survivor moves into collective formulas to express grief. That harsh and distinctive «iAy Muerte! muerta seas, muerta, e mal andante, / mataste a mi vieja, matases a mí ante» that initiates Juan Ruiz's narrative of grief is counteracted by the predictable string of commonplaces regarding attitudes about death (Ruiz, 1520 , 424). This particular lament ends up with «el pitafio de la sepultura de Urraca» in which the very voice of the deceased buries any sign of the survivor's individuality in his expression of pain. In this final stanza we can see how even the individual voice of the deceased is still filtered through tradition and its expression is rife with commonplaces. See: G.B. GybbonMonypenny, ed. (1988), Juan Ruiz, Libro de buen amor, Madrid, Castalia. 
action that echoes the shift from the collective to the individual and the rise of the individual that characterizes modernity. As Tammy Clewell points out in her study of Freud's «Mourning and Melancholia,» working through grief is an important theoretical perspective which assumes "a model of subjectivity based on a strongly bounded form of individuation" (2004: 1). Moreover, far from being a process exclusively determined by a set of rules that have the same effect on every person, the expression of grief corresponds to a highly individualized and dynamic process that even in the same person varies from moment to moment (Shuchter and Zisook 1993: 23). This strong individual component is, of course, always a function of the specific historical time and cultural mentality in which it is expressed, either to conform to it or to subvert it. It is the sense of individuality, as conceived of in a specific historical period, which determines the expression of grief. In turn, grief is always subjected to, and at the same time brings about, change and transformation. As the emotion that governs our responses to crisis or to changes that interfere with daily life, such as the death of a loved one, grief is then necessarily a discursive, highly individual, and transformative concept. ${ }^{7}$

These characteristics of modern grief are formulated by Fernando de Rojas, who in 1499 crafts a literary example manifesting a double shift in the expression of grief: from the collective to the individual, and from the deceased to the survivor. It is in this context of self-awareness and new attitudes towards life and death that Pleberio's lament emerges bringing along the voice of the early modern survivor; a survivor whose narrative of loss aims at highlighting his own identity over the memory of the deceased, thus emphasizing two of the trademarks of modernity: individuality and subjectivity. ${ }^{8}$ Pleberio's narrative of grief silences the medieval

7.- We first glimpse this change in perspective in Diego de San Pedro's Cárcel de amor (1492). This is one of the first and most popular inkling of the shift from collective to individualized responses to death on the part of survivors as illustrated by a mother who laments her dying son, Leriano, a wretched young man dying of love. Here we find a timid effort of this mother to establish her own individuality when she asserts «Hoy dexas [de] dezir[te] hijo y yo de llamarme madre» (San Pedro, 154). However this motherly 'I' is immediately silenced by the formula of commonplaces prescribed by the genre of elegiac literature, which taints grief as a one-dimensional and non-evolving state: first, presentation of the particular death, followed by lament focused on the deceased, praise of the dearly departed, consolation, and acceptance. See: Keith Whinnom, ed. (1971), Diego de San Pedro, Cárcel de amor, Madrid, Castalia. For a detailed comparison between Pleberio's lament and that of the Duchess Coleria, mother to Leriano, see Luis Miguel Vicente, (1988), «El lamento de Pleberio: Contraste y parecido con los lamentos de Cárcel de amor», Celestinesca, 12.1, pp. 35-43; Dorothy Severin, (1989), «From the Lamentations of Diego de San Pedro to Pleberio's Lament.» The Age of the Catholic Monarchs 1474-1516: Literary Studies in Memory of Keith Whinnom. Liverpool, University Press, pp. 178-84.

8.- The concept of individuality has often used as a catchall term that has been variously interpreted as involving one or more of the following: indivisibility, difference, division within a species, identity through time, unpredicability, and non-instantiability. The present study examines the construction of individuality in a context of death as formulated through the re- 
third person voice and privileges an autobiographical narrative in which the deceased is replaced by the survivor as the victim of death. As we will see, here grief is constructed as a pragmatic narrative emotion that, by means of the survivor's psychological introspection, evolves on multiple levels. Not only does Celestina perfectly illustrate the ethos of the egocentric twist towards the self that characterizes early modernity, but it also allows us to witness the surfacing of an individualistic narrative of grief in which the medieval collective sentiment towards death yields to the early modern desire for individual introspection, even in death.

\section{The Pleberian Concept of Loss: Between Emotional Deficit and Economic Failure}

Celestina is a text that revolves around the tension between gains and losses, both material and human. It centers on the love story of Calisto and Melibea, which ends in tragedy: Calisto dies accidentally whereas Melibea commits suicide in hopes of being reunited with her lover. The story culminates in the lament that Pleberio, father to Melibea, crafts upon witnessing the self-inflicted death of his only child. Pleberio's introspective response to Melibea's death illuminates the ambiguous, and often contradictory, nature of grief. By shifting the focus from his daughter to himself, Pleberio sketches the guidelines for a new model of mourning that makes of grief an introspective and personal process whose expression evokes an ethical dilemma regarding the relationship between survivor and deceased. As R. Clifton Spargo puts it, "does grief primarily concern the ego as if our every expression of sympathy were merely a matter of extending the ego's narcissistic satisfaction to the realm of the other?» (2004: 24). ${ }^{9}$ In other words, is grief for the living or the dead?

Pleberio is a unique character in terms of the relationship that Rojas has established between death and the characters in Celestina. Indeed, the ef-

lation between loss and language which serve as differentiators. For this definition I am drawing from the entry of 'individuation' provided by The Cambridge Dictionary of Philosophy (1995), page 367. Additionally, in the present essay I employ an approach that combines the ideological spaces circumscribed to the concepts of 'subjectivity' and 'individuality, as defined by Kaja Silverman. As she indicates, the latter term dates from the Renaissance and bears the traces of the dominant philosophical system of the times, which afforded to consciousness the very highest premium. The concept of subjectivity, on the contrary, gives a more central place to the unconscious than it does to consciousness (1983: 126). See: Kaja Silverman, (1983), The Subject of Semiotics. New York, Oxford UP.

9.- For the connection between ethics and mourning see R. Clifton Spargo's definition in his The Ethics of Mourning (2004). He employs the term 'moral' or 'morality' "most often when referring to the conventions, regulations, or parameters of knowledge that determine behaviour," and the term 'ethics' to refer to more basic structures of relationship as well as to the critique that motivates and conditions 'all' moral knowledge» (2004: 8). 
fect of death upon Pleberio singles him out because he is an individual whose suffering "is made yet more moving by the realization that, unlike other characters of the work, Pleberio's dilemma will not soon be terminated by death but will endure» (Flightner 1963: 81). Melibea has committed suicide, which suggests that she will not have the solemn mass that traditionally takes place the day after the demise. Pleberio, then, will not have the healing closure that such a ritual is intended to provide, a fact that highlights the prolongation of his pain. It is precisely this emphasis on the survivor's "life after» which allows Rojas to interrogate grief as an introspective and linguistic process that shapes an individualistic attitude towards loss.

Pleberio's process of self-examination begins immediately upon witnessing the fatal event. Holding Melibea's dead body in his arms, he breaks the news to his wife, Alisa. From the very beginning the wretched father sets the tone of his lament by constructing her daughter's demise as an absolute loss for the family unit: "iAy, ay, noble mujer," he cries to his wife, «nuestro gozo en el pozo; nuestro bien todo es perdido; no queramos más bivir!» (Act XXI, 336).${ }^{10}$ Rather than emphasizing his daughter's death - he does not express concern for Melibea's suffering, condemnation, or loss of her life-, Pleberio's opening words suggest that he is more preoccupied with the idea that death has stolen their daughter from them than with the fact that Melibea has lost her life. The focalization of Melibea's death in her father's narrative begins by privileging her parents' perspective of their loss. Pleberio's focus on their own position as survivors inheres in his choice of words, which immediately underscore their condition as victims. Along with the possessive "nuestro,» the second person plural of this initial passage emphasizes the loss of personal possession at the same time as it draws attention to the fact that this narrative of grief rests on the perspective of the survivors, a perspective always voiced by Pleberio. The tragic event itself seems to be relegated to second place by highlighting not Melibea's death but rather the effects that her suicide has on her parents: the survivors, along with the deceased, are also turned into victims. Melibea is perceived as the object of the narrative that frames her as a marginal addressee of a discourse determined by biological undertones: she becomes tangential, defined as the offspring of parents who have lost a daughter.

From Pleberio's point of view, Melibea's death qualifies as an emotional loss or deficit whose effects are expressed by means of a lexicon and

10.- All references to Celestina come from Dorothy S. Severin's 1998 edition. Behind the comic effect of this expression as a reaction to the death of a dear one, David Pattison notes, lies a crude truth that characterizes the representation of death in Rojas' work: "In Celestina those who die are mourned [...] because their passing spoils things for other people; death is not only messy, it is also grossly inconvenient» (2001: 143). See: David Pattison (2001), "Deaths and Laments in Celestina,» Bulletin of Hispanic Studies LXXviII, pp. 139-143. 
imagery borrowed from the world of economy. ${ }^{11}$ Pleberio's narrative of grief feeds on the idea of possession from the moment he characterizes Melibea with the word «bien.» As Alan Deyermond indicates, the noun 'bien' is an ambiguous term, "signifying 'the only thing that matters to us' ... but also evoking the concept of 'bienes', worldly goods» or property (1990: 172). On one hand, this term identifies the young woman as a valuable possession in the sentimental space of her parents; however, this word simultaneously evokes and foreshadows the economic imagery that pervades Pleberio's lament. The loss of Melibea stands, then, in a delicate balance between an emotional shortfall and an economic deficienc.

The Diccionario de Autoridades reminds us of this linguistic ambivalence. The word «bien» evokes the connotations of "aquello que en sí mismo tiene el complemento de la perfección tocante a su propio género,» but it also means «beneficio, provecho, adelantamiento, utilidad» (Diccionario de Autoridades, 603). This wordplay underscores the fact that Pleberio's loss is thus simultaneously tinged with a sense of deficit in which the emotional loss intermingles with a sense of economic failure. This double meaning qualifies Melibea as an essential 'good' as suggested by the word "todo," which indicates that nothing else can match or substitute this lost object. ${ }^{12}$ By means of his language Pleberio conveys the sense of being deprived of an essential component of his existence, as he implies that Melibea's loss is absolute for it comprises all the possible losses that they can have. For Pleberio all is lost at once, thus suggesting that there is no hope. His opening words, therefore, highlight the desperate position of both his wife and himself as survivors of the death of a daughter who is constructed as a vital component of her parents' existence. Melibea's loss thus unleashes the desire for death as voiced by Pleberio with "no queramos más bivir» (Act XXI, 336).

As viewed in Pleberio's narrative, Melibea is then an object whose value oscillates between the emotional and the economic: as a survivor Ple-

11.- This technique was common among Renaissance sonneteers who often express the loss of a lover in economic and financial terms. As R. Clifton Spargo points out, financial concerns are also common in Renaissance elegies, which «may be owing in part to the emergent bourgeois ethos of Protestantism, so that the loss of the other, when represented as a type of financial transaction, pertains to matters of both social and metaphysical economy» (2004: 94). It is worthwhile to notice, though, that in Pleberio's lament the financial conceit is transformed into a mercantile metaphor privileging the outcomes of economic transactions as a result of individual entrepreneurship rather that its means. The abstraction of finance is then transformed into the concrete literality of products.

12.- This sense of irreplaceability is reinforced by the fact that Melibea is Pleberio's only child whose loss cannot be compensated by another sibling. Additionally, as Joseph Snow also indicates, it is important to bear in mind that Pleberio has lost his daughter twice: first, with Calisto, and second, with her death. Therefore when Pleberio and Alisa lose Melibea, "when she is no longer theirs, when she throws all breeding, caution, and shame to the winds, destroying the family (or at least when Pleberio and Alisa come to know of this), then it is manifestly true that 'faltándoles ella, fáltales todo el bien' (III, 84)» (Snow 1990: 388). 
berio is impoverished both economically and emotionally by the absence of his daughter. This duplicity allows us to view his initial response to Melibea's suicide as the legacy of medieval culture which gives way to the materialistic discourse of modernity. The equating of Melibea with a worldly good echoes the fact that medieval society expressed its concern with material possessions by means of a correlation between attitudes toward wealth and death (Ariès 1982: 193). ${ }^{13}$ However, Rojas takes this concern further by combining the economic and the sentimental in order to shape Melibea's death as Pleberio's exclusive loss. As Beverley Raphael points out, in some families the children «are ... allocated to a parent one child may 'belong,' as it were, to one particular parent» (1983: 267). In the social system of the Renaissance this loss is necessarily a gendered one, a patriarchal one; it is then no surprise that Melibea 'belongs' to her father, as illustrated when he despairs using the first person possessive adjective: « $\mathrm{O}$ mi hija y mi bien todo, crueldad sería que biva yo sobre ti!» (Act XXI, 337). ${ }^{14}$

Pleberio's narrative of grief has then suddenly switched its focus to himself. The pronominal connotations of self-reference quickly shifts from the plural to the singular form drawing our attention to him as the sole survivor, as both the subject and object, speaker and addressee of his own account. Melibea's death, then, figures in terms of the loss of a unique commodity that cannot be replaced, a realization that leads Pleberio to qualify his loss as "incomparable pérdida» and serves as the catalyst for the egocentric tone of his narrative, as illustrated by his self-interested comment: «Ninguno perdió lo que yo el día de hoy» (Act XXI, 340). ${ }^{15}$

If Rojas has initially used the ambiguous nature of the word "bien» to suggest the economic undertone that inheres in Pleberio's loss, now the author employs increasingly concrete imagery to build the character's identity as survivor of his daughter's death: « $\mathrm{O}$ duro coraçón de padre!

13.- According to Ivy Corfis, this materialistic approach to grief «adds to the irony found in the lament and elsewhere in the work» (2001: 49). See: Ivy Corfis (2001), "Imagery of Love and Death in Pleberio's Lament», Celestinesca, 25.1-2, pp. 47-56.

14.- Ivy Corfis' explanation of the medieval right of fathers over children supplies the legal background for this relation of ownership. See: Ivy Corfis (1991), "Laws of the Household in Celestina», Romance Language Annual, 3, pp. 397-401.

15.- This insistence on individual loss seems to indicate that there is no apparent sorrow for Melibea herself, for the young life cut short or even for the loss of heaven ensured by the act of suicide as prescribed by the reigning Catholic ideology. Pleberio never expresses concern in this regard, even though suicide was the worst kind of death because it is caused by desperation by which «no se alcança otra cosa alguna sino que por ella el muy piadoso Dios mucho más se offende, e los otros tus pecados se agravian más» (Arte de bien morir 96). In this sense, Eukene Lacarra notes that «la muerte de Calisto precipita el suicidio de Melibea, que se dramatiza casi punto por punto como una inversión del Arte de bien morit» (2007: 196). For a very thorough treatment of suicide in Celestina see Eukene Lacarra Lanz (2007), «La muerte irredenta de Melibea", Actas del Simposio Internacional 1502-2002: Five Hundred Years of Fernando de Rojas' 'Tragicomedia de Calisto y Melibea.' Ed. Juan Carlos Conde. New York, pp. 173-208. 
¿cómo no te quiebras de dolor, que ya quedas sin tu amada heredera? :Para quién edifiqué torres; para quién adquirí honrras; para quién planté árboles, para quién fabriqué navíos?» (Act XXI, 337). ${ }^{16}$ Along with the emotional capital that this passage emphasizes, Pleberio individualizes his suffering by filtering it through the economic and social standing that his profession has produced. He is a rich merchant who has acquired wealth and a high social position by means of a life dedicated to commerce, and who had hoped to use these privileges to further improve his standing by arranging a lucrative marriage for his daughter. ${ }^{17}$ Rojas uses Pleberio's property to consolidate his individualization because if taken literally, by means of his words "we learn that he built towers, constructed ships, planted trees, and acquired honras; the verbs are all in the first person singular and Pleberio's own active involvement is thus stressed even if that involvement was merely that of an instigator and paymaster of the operations concerned» (Hook 1978: 28). ${ }^{18}$

The overall mercantile effect that tinges Pleberio's narrative manifests the relationship between individuality and the notion of grief. He is differentiated as a survivor because his identity is constructed by choosing the fruits of his capitalistic acumen as a means to both mediate and express his pain for Melibea's death. First, Pleberio's "torres,» "árboles» $y$ "navíos» impart a sense of concrete materiality to his despair: for this father losing his daughter is a quantifiable emotional and physical loss. Both the material and intangible levels of this loss collide more clearly in the word "torres.» Subverting the literary topos of the imprisoned lady in the tower, Rojas locates Melibea's final act in a tower, an architectonical element that serves as the «materialización efectiva de ese ámbito de la ausencia irreparable» (Varela-Portas 2001: 577). ${ }^{19}$ In this context, the

16.- This reaction parallels that of Calisto regarding Sempronio and Pármeno's deaths which is adequately distraught but purely selfish: «... veo la mengua de mi casa, la falta de mi servicio, la perdición de mi patrimonio, la infamia que a mi persona de la muerte de mis criados se ha seguido!» (Act xiv, 288). As Pleberio does, Calisto also channels his pain through his worldly possessions which extend to his servants, on whom his patrimony depends, just as Pleberio's depends on Melibea. However, as indicated by Lida de Malkiel, a substantial difference between both attitudes is that concerning Pleberio, the author's intention is «acentuar como su vida toda giraba en torno a Melibea» (1962: 473). See: María Rosa Lida de Malkiel (1962), La originalidad artística de La Celestina, Buenos Aires, Editorial Universitaria de Buenos Aires.

17.- Let's recall here Pleberio's words to Alisa in Act XVI: «Demos nuestra hazienda a dulce successor; acompañemos nuestra única hija con marido, cual nuestro estado requiere, por que vamos descansados y sin dolor deste mundo» (Act XVI, 302). In this light, David Pattison asserts that Pleberio «is concerned much more for his own loss, his blighted old age —and in particular for the ruin of his dynastic plans — than any other reason» (2001: 141).

18.- In contrast to this assertion, Frank Casa suggests that Pleberio's words do not indicate his commercial activities but they refer rather to a state of mind: «Pleberio's remarks should be considered as an admission of a lack of perspective by the grieving father» (1968: 23).

19.- For a further discussion on the symbolism of the tower in various Spanish texts, see Hook (1978): 29-30. 
tower creates an image of tragic irony: it is Pleberio himself built the structure from which Melibea leapt to her death, and that now will be the memoralization of her self-inflicted tragic end. Literally the tower becomes the constant and concrete reminder, the monumental presence that will remind Pleberio of Melibea's absence through a discourse that combines architecture and family.

As José Antonio Maravall notes, in many works in the second half of the $15^{\text {th }}$ century «se insiste en el crecimiento constructor, se habla del impulso por levantar edificios para albergar en ellos la existencia familiar.» Maravall interprets this insistence as a reflection of what he calls incipient "energías individualistas» that flourish in that period and are echoed in Pleberio's attitude (1978: 256). As indicated by these words, Pleberio fathers a narrative that situates the survivor's "I» at the center rather than at the margin of the painful experience that it depicts. Furthermore, Melibea does not appear in this passage: her existence is implicit, serving only as the pretext for her father's actions and emotions. Here it seems that Pleberio's lament focuses on the pragmatic outcomes of his endeavours based on the notion of the autonomy of the individual, which is exactly what death countermands.

From this perspective, Rojas seems to be defining this survivor as an individual who is more concerned with preserving his own patrimonial legacy via his daughter than conserving her memory. Rojas' use of the word 'heredera' in connection to Pleberio's achievements suggests that he, just like most of the characters in Celestina, is principally concerned with the loss of his individual profit ${ }^{20}$ This materialistic perspective suggests that he sees Melibea as an object whose value is based on her instrumental condition as the inheritor of his possessions. I am not sug-

20.- As it has been noted by several scholars, the use of the term 'heredera' indicates that Pleberio conceives Melibea's death as part of an economic system that constructs his daughter's life as the object of a commercial transaction. "Melibea's destiny,» notes Alan Deyermond, "was to inherit the carefully accumulated wealth; her economic function, in Pleberio's minds, displaced her identity as an autonomous person» (1990: 176). As Angel Sánchez indicates, the term "heredera» evokes the idea that in Celestina "las relaciones entre humanos están presentadas en base a unos valores que cosifican a los hombres al contemplarlos como objetos de una operación mercantil centrada únicamente en la consecución de un beneficio económico» (1994: 65). See: Ángel Sánchez, (1994), «Mercantilismo, sociedad y algunos personajes de Celestina,» Torre de Papel 4.3, 59-71. Peter Dunn reconfirms this particular trend in Celestina, a trend by which «individual relations are transformed into commercial ones» (1976: 416). Additionally, he perceptively points out that when Pleberio calls to his wife to share his grief, Melibea is not just the lost daughter of a grieving father, but the lost heir of a man of property: «note how he correlates 'padre' (father) not with 'hija' (daughter), but with 'heredera' (heir)» (Dunn 1976: 414). However, as Luis Miguel Vicente suggests, the term "heredera» also highlights Pleberio's individuality. In this lament, Vicente notes, «faltan los elogios a la difunta, en cuanto a su valor en sí misma, aunque se magnifica su valor como heredera» (1988: 36). Vicente concludes that due to Melibea's condition as heiress, «Pleberio prides himself on having lost more than those other fathers from Antiquity that he alludes in his speech» (1988: Footnote 4, 42). 
gesting, however, that Pleberio exclusively thinks of his loss in economic terms; he reacts to Melibea's death emotionally as well. ${ }^{21}$ What I wish to indicate is that in Pleberio's expression of grief the mercantile discourse interacts with the emotional in order to individualize him as a survivor. What is important in order to examine Pleberio's enactment of grief, I argue, is that Melibea is qualified simultaneously as "hija,» "bien,» and "heredera:» an amalgam of roles that underscores the emotional complexity of Melibea's position vis-à-vis her father.

This combination of deep emotion and mercantilism that converge in the term 'heredera' informs Pleberio's painful conflict between his social self, as merchant and patriarch, and his more intimate emotional self as father. In fact, this association suggests that he is affected by his daughter's death on two apparently paradoxical levels, the emotional and the economic. Beyond its financial connotations, 'heredera' is also charged with emotional force as it evokes an image in which Pleberio's past, present, and future merge in a tragic way. The past is represented by Pleberio's efforts during his life to literally build a patrimony to pass on to Melibea. Towers, trees, boats, and lands then, represent Pleberio's patrimonial narrative fabricated in the past, with existence in the present, and projection towards the future. This enumeration of achievements that will be left inherited - orphaned in a sense- manifests the tension between continuity and remembrance but applied to the survivor rather than the deceased as «it is the living who are afraid that their lives will make no difference, will be meaningless, and will go unremembered» (McGowan 2002: 304). ${ }^{22}$ Death has indeed truncated Pleberio's life narrative by eliminating the only element that could propel it into the future: Melibea. It is now, in this void created by Death, that the echo of Pleberio's own words in Act XVI resonates loud and clear: "Demos nuestra hazienda a dulce successor» (Act XVI, 306). Death prevents the continuation of Pleberio's work and the perpetuation of his identity in the form of the material goods that Melibea should have inherited thus keeping her father's legacy alive. Melibea's demise therefore entails Pleberio's social death by erasing posterity even before it has been written.

21.- A sector of the criticism on Celestina has charged Pleberio with total indifference to the dishonor of his daughter, failure to seek consolation in God, and selfishness in considering the event exclusively from his own point of view. However, as Frank Casa indicates, Pleberio has just experienced the violent death of his daughter: «Should he worry about her lost honor; that is, should he stop to consider the social impact of what has been revealed to him or should he feel only the piercing pain caused by the collapse of his world (1968: 22). Along these lines, Alan Deyermond notes, that «it would, of course, be unfair to suggest that Pleberio thinks of Melibea only as a lost investment, yet there is no doubt that this aspect is prominent in his mind» (1990: 173).

22.- In this sense, José Antonio Maravall notes that Pleberio seems to be very upset regarding the idea that "todo ello va a quedar sin alguien que pueda sucederle» (1976: 45). See: José Antonio Maravall (1976), El Mundo social de "La Celestina," Madrid, Gredos. 
The fine balance among the emotional, the economic, and the fleeting nature of time that characterizes Pleberio's narrative of grief is furthered reinforced when he addresses Fortune: ${ } \mathrm{O}$ Fortuna variable, ministra $y$ mayordoma de los temporales bienes!, ¿Por qué no executaste tu cruel yra, tus mudables ondas, en aquello que a ti es subjeto? ¿Por qué no destruyste mi patrimonio; por qué no quemaste mi morada; por qué no asolaste mis grandes heredamientos?» (Act XXI, 338).

Pleberio appears to be focusing on Melibea by trying to bargain with death, which is one of the stages of grieving identified by the eminent psychologist Elizabeth Kübler Ross. ${ }^{23}$ However, he does not say what would be expected within the tradition of sparing the young: the "why not take me instead?» Instead of offering his life for his daughter's, Pleberio offers his possessions. The repetition of the possessive adjective "mi» in conjunction with the laundry list of his material markers of class and wealth creates a narrative that emphasizes the bereaved's social position. Pleberio's enumeration of his possessions indicates that he specifically relates Melibea's death with his worldly achievements, thus highlighting his subject position as an individual survivor as he materializes the anguish caused by thinking about the possessions that, due to Death's intervention, will remain uninherited. It is true that Pleberio's words evoke the common bargaining response characteristic of grief of 'take me not my child', but the language he employs draws attention to himself by turning Melibea into an invaluable commodity.

With Melibea's death, past, present and future collide as Death has truncated Pleberio's intentions and has transformed all his economic efforts into "trabajo sin provecho» (Act XXI, 338), which indicates that Pleberio perceives his loss as a fruitless labor with emotional consequences. As unfinished business relating to the plans that the survivor had for the deceased, this loss also implies a negative outcome for Pleberio's future as suggested when he cries: «¿dónde hallará abrigo mi desconsolada vejes?» (Act XXI, 338). As Beverley Raphael reminds us, in losing a child «the parent loses not only the relationship but a part of the self and a hope for the future» (Raphael 1983: 281). Melibea's death unveils Pleberio's patriarchal anxiety regarding aging as he clearly feels that the sense of security of his "desconsolada vejes» has been tampered with: Pleberio's future has been stolen along with Melibea's. ${ }^{24}$

23.- In her seminal On Death and Dying (1970), Kübler-Ross outlines five stages of grief, a model which serves as the basis for our present day understanding of bereavement.

24.- For a provocative analysis of masculine anxieties under the reign of the Catholic Kings see Barbara Weissberger (2003) Isabel Rules: Constructing Queenship, Wielding Power, Minneapolis, University of Minnesota Press. 


\section{III. «Desconsolado viejo, ¡qué solo estoy!»: The Failure of Community}

Rojas carefully stages Pleberio's demonstration of grief in such a way that this wretched father occupies the central position both in his lament and Celestina's final act. That is, Pleberio is the sole protagonist of a self-centered story that he tells alone and, as the last voice in the text, he has the last word. Although Rojas surrounds him with other characters, he delivers his narrative of grief completely alone throughout the whole scene: Lucrecia remains voiceless during Pleberio's speech and Alisa faints after her husband delivers the tragic news. All those surrounding him remain unresponsive thus highlighting Pleberio's utmost isolation. The staging of Pleberio's solitude goes beyond being a simple strategy to achieve a dramatic effect. In fact, regarding the importance of the motif of loneliness, as Emilio de Miguel Martínez points out, "la efusión de los sentimientos personales de desolación y soledad no sólo es el motivo recurrente que se prodiga - a él se retorna sistemáticamente desde cualquier otro de los temas-, sino que es el motivo que abre y cierra el monólogo» (2001: 184). Pleberio's isolation foregrounds him, allowing Rojas to sustain the shift of focus in this father's narrative of grief from the deceased to the survivor.

Loneliness sets the individualistic tone of Pleberio's speech right from the beginning when he addresses his wife in the following manner:

«Y por que el incogitado dolor te dé más pena, todo junto sin pensarle, por que más presto vayas al sepulcro, por que no llore yo solo la pérdida dolorida de entramos, vez [sic] allí a la que tú pariste y yo engendré, hecha pedaços» (Act XXI, 336).

Not only does Pleberio open his narrative by placing the emphasis on the grieving «I» rather than on the deceased «she,» but also he highlights the fact that this grieving "I» is afraid of being alone. Pleberio draws attention to himself regarding the possibility that he might be left alone to lament their loss. His words not only suggest a kind of patriarchic emotional responsibility to bemoan Melibea's death, as he is appropriating as exclusive the pain caused by his daughter's suicide, but also construct this wretched father as a lonely sufferer.

That Pleberio seems to be most preoccupied with his loneliness as a survivor is further emphasized by his desperate request to his wife: "Ayúdame a llorar nuestra llagada postremería» (Act XXI, 337). This cry for help proves to be sterile as Alisa never responds to her husband's initial request. We soon learn that she has lost consciousness while holding 
her daughter's corpse. ${ }^{25}$ Suddenly and utterly alone, Pleberio exhorts her: "O mujer mía, levántate de sobre ella, y si alguna vida te queda, gástala conmigo en tristes gemidos, en quebrantamiento y sospirar; y si por caso tu spíritu reposa con el suyo, si ya as dexado esta vida de dolor, :por qué quesiste que lo passe yo todo?» (Act XXI, 337). However, Alisa fails to respond. Her silence serves as a dramatic device employed by Rojas to convey the idea that Pleberio's grief is entirely personal and private, not to be shared even with the only other individual so affected by Melibea's death: her own mother.

Pleberio's state of abandonment as a survivor is made more poignant by Rojas' highlighting the overwhelming need of this character for an active interlocutor as an addressee of his narrative of grief. Pleberio now invokes the presence of an imaginary support group of onlookers that would potentially help him mourn his loss: ${ }_{i} \mathrm{O}$ gentes que venís a mi dolor, o amigos y señores, ayudadme a sentir mi pena!» (Act XXI, 337). Under an imagined public gaze Pleberio invokes the collective because in his mind his narrative needs an audience in order to exist: that is, he can only be a grieving subject when he communicates his pain to others who, in turn, bear witness and recognize him as a survivor. Pleberio is projecting by invoking this invisible community, a frustrated attempt that further emphasizes his loneliness and position as a lone survivor. The answer to his desperate request to help him mourn his loss is silence, thus suggesting that Pleberio will not be able to feel support for his grief as, by having failed to be recognized by others, his pain has not been validated. ${ }^{26}$ The silence that Pleberio receives for an answer on both the real level - Alisa and Lucrecia - and imagined level - the group of onlookers- construes this survivor as an individual left to mourn his loss alone. As a result, mourning, understood as the public dimension of grief, is not possible at this moment because there is no community to provide the ritual structures for this public manifestation of pain, thus exerting on Pleberio a twofold effect: the lack of a collective ritual prevents social acknowledgement on a symbolic level, which in turn generates loneliness for the individual on the psychological level. ${ }^{27}$

25.- David Hook suggests that Alisa could also be dead as a result of the pain caused by Melibea's death (1978: 25). Interestingly enough, this situation engages the question that Colin Parkes posits when examining surviving widows both in England and the United States: «Is grief a cause of death?» (1975: 14-28).

26.- The silence that embodies Pleberio's lament stands in clear contrast with the loud staging of Melibea's suicide which emphasizes the noise of the imagined community when she addresses her father saying «Bien oyes este clamor de campanas, este alarido de gentes, este aullido de canes, este [grande] estrépito de armas» (Act Xx, 333).

27.- The tension between the private and the public in the context of the lament has been studied by Bruce Wardropper. For Wardropper Pleberio's grief is individualistic and personal, not public. He is an old man «mourning the violent death of a young person [...] Pleberio allows his selfish concern with his own life to intrude his sorrow» (1964: 144). Wardropper 
It seems obvious at this juncture that Rojas has taken great care in presenting Pleberio's enactment of grief as a one-man show. The desperate call for an imagined community, along with the silencing of his wife, is symbolically charged in a twofold manner: first, Rojas is further emphasizing this wretched father's loneliness as he seems to suggest that the old traditional ways of collective mourning no longer serve the new individual. Additionally, Rojas is casting aside the ceremonial trappings of tradition. He thus inaugurates the modern narrative of grief as one that is based on the private rather than in the public. Modernity, then, turns collective engagement in mourning into an individual act of responsibility.

Without a grieving community to support him, Rojas has submerged Pleberio in the utmost loneliness. In this case, however, the disappearance of the social dimension of mourning qualifies Pleberio's manifestation of grief as «individual mourning.» Without active interlocutors, he is forced to serve as both the speaker and addressee of his own message, which in turn highlights his marginalized position as a survivor. What should have been a symmetrical or reciprocal rite, following RadcliffeBrown's terminology (1964: 134), becomes an asymmetrical rite parallel to that of Alisa's embracing Melibea's corpse; that is, there is no response to Pleberio's suffering. In this sense, as Michael Gerli points out, "the communication of suffering and thus its amelioration is precluded by Pleberio's solitude. The equality, and at once paradoxical loneliness, of death is sinisterly inverted and suddenly applied to life» (1976: 70).

Pleberio's isolation is even more poignant as it appears to be the legacy of his own daughter who, before committing suicide, seems to have cursed her father when she asserts: «De todos soy dexada ... Gran sinrazón hago a sus canas, gran ofensa a su vejez; gran fatiga le acarreo con mi falta; en gran soledad le dexo" (Act Xx, 331). ${ }^{28}$ Having sought in vain to share his grief, the unsupported «I» irrupts as the only voice in the midst of this emotional devastation. Pleberio's lament revolves around a surviving and abject «I» that refuses to vanish by emphasizing his individuality at the moment when, abandoned by others, grief becomes the most deep and pervasive.

The collapse of a potential community of mourners leaves Pleberio facing his tragic circumstances in the most complete loneliness; that is, he is forced to take sole ownership of his pain. For this survivor, then, grief seems to be an impetus for personal growth as it sparks a process of psychological introspection. Rojas eagerness to have his protagonist grieve

insists on the private characterization of Pleberio's grief when he reminds us that «as the planctus is transposed into the vernacula, then, its themes cease to be public, and become personal» (1972: 129). See: Bruce W. Wardropper (1972), «The Funeral Elegy of the Spanish Renaissance,» MLN 87.6, pp. 126-143.

28.- In fact, Melibea's words single out her father as the only collateral victim of her selfinflicted death. Only at the very end of her speech, does Melibea utter a formulaic «Salúdame a mi cara y amada madre» (Act xx, 335). 
in isolation against traditional paradigms transforms Pleberio's expression of grief into an act of individual dissent. Pleberio's almost obstinate decision to continue expressing his pain, in spite of being completely abandoned, allows Rojas to project his protagonist's lament into the realm of ethics because, as R. Clifton Spargo points out:
though it may be imaginatively convenient to configure a stubborn act of mourning with the report of an injus- tice done to the one who is being mourned, a mourner's willingness to oppose those cultural norms that preside over his society's attitude toward death is what gives to mourning its ethical connotations (2004: 5).

Pleberio's position as an isolated survivor is further reinforced by the significant number of rhetorical questions that Rojas employs throughout this lament. This strategy determines how we perceive Pleberio's inner emotional world because as these questions are being formulated we gain access to his obsessive ruminations in connection to Melibea's death. ${ }^{29}$ These rhetorical questions serve as a metaphor that stands for the loneliness surrounding Pleberio; that is, the sense of isolation which emerges from a series of impassioned questions that goes unanswered. They portray Pleberio's extreme despair as the emotional desolation that he feels is reflected by the emptiness that the string of thirty-eight rhetorical questions creates: thirty-eight questions asked with no hope of obtaining even one single answer. ${ }^{30}$

The function of these questions has attracted much scholarly attention. In his analysis of Pleberio's interrogation of Fortune, David Hook indicates that these questions could reveal Pleberio's anguish that his daughter will not inherit his estate. Pleberio, Hook reminds us, is "perfectly aware of the answer and is, by these rhetorical questions, simply lamenting the demise at one and the same time of his daughter and his hopes» (1978: 28). Peter Dunn, however, indicates that "we must ask whether such words imply conclusions by Pleberio about God and the universe or whether they are simply and spectacularly appropriate to a man whose very ordinary mind has never before faced a disturbing question» (1976: 412). For his part, Frank Casa sees these questions, which emerge in response to a bitter experience, as a sterile exercise that necessarily lacks an answer. According to Casa, these questions are left unanswered because they are beyond the capacity of Pleberio or Rojas to answer them (1968: 29).

29.- It is interesting to notice that among these questions Rojas has excluded the ubi sunt, which suggests that he is breaking away from the medieval patterns using the rhetorical question as a way to emphasize personal introspection rather than by following the traditional formula.

30.- According to Bruce Wardropper, this lack of answers resonates with the unsatisfactoriness of the answers found in elegiac writing (1964: 148). 
Although with different implications, these interpretations converge on a man left alone in desperation, which is precisely what these rhetorical questions help to emphasize. These vain invocations, then, not only echo the loneliness and abandonment produced by others but also shift the focus to Pleberio himself as the perpetuator of his own loneliness: by articulating questions that he cannot answer Pleberio seems to seek consolation in a sterile allegorical "why" which emphasizes his condition as a solitary survivor. As a skillful man of letters and feelings, Rojas sensed that nothing could speak louder or more clearly about Pleberio's feelings than the silence embodied in the dramatic emptiness of an answerless question, which in turn makes Pleberio both the subject and the object of his narrative of grief. In fact, the lament as a whole, then, becomes a suffocating rhetorical question by the fact that Act XXI is framed by the questions of Melibea's progenitors. The function of these questions within Rojas' staging of Pleberio's grief parallel, then, that of all the interlocutors of this character's narrative (people and friends, his own white hairs, his heart, Fortune, Love, the World, himself, his wife, and his Melibea's dead body): the collective silence of ten interlocutors and thirty eight questions work together to leave Pleberio alone at the center of his grief.

\section{IV. "¿Qué haré de que no respondas si te llamo?»: the Abandonment of Language}

This lack of response to Pleberio's request to grieve within a community, along with the silence that inheres in each of the rhetorical questions employed by Rojas unavoidably draws our attention to the absence of the very means of communication: language. Since they lack an answer, these inquiries become a self-centered device that highlights the very words that compose them. They allow us to look at the words that Pleberio uses to narrativize his pain but also encourage us to peek at what lies behind them: the incapacity of language to capture the object of his narrative, Melibea. As they reveal Pleberio's subconscious these questions serve as reminders of language's perpetual failure thus increasing his abjection as a survivor. Grief and language set limits for each other as Pleberio's point of reference for his final speech is an experience that originates in an absence that words cannot not turn into presence. These unanswerable and unanswered inquiries manifest that Pleberio's narrative of grief will always be in a permanent state of desire for its unattainable object.

In literature, remembering the dead takes the form of storytelling. After all, «every death creates a story, or set of stories to tell» (Sedney 1994: 287). In Celestina grief cannot exist outside the realm of language and desire - stories of grief for the dead are linguistic in nature and they exist only in a state of continuous desire as their object must be kept perma- 
nently absent - and paradoxically, language fails to allow the survivor to fully embody this feeling thus perpetuating the desire for the deceased. ${ }^{31}$ Grief, then, is presented as a linguistic process that, articulated by the survivor who tells the story from the position of a present «I,» follows the direction of the deceased, an absent «she» or "he.» That is, grief unites both the deceased and the survivor in a space that can only exist through a narrative. As John McGowan indicates

$$
\begin{aligned}
& \text { the dead are remembered through their location in nar- } \\
& \text { ratives that recount their deeds and their way of being } \\
& \text { in the world. These narratives create significance by de- } \\
& \text { tailing the connections between the dead and the others } \\
& \text { before whom and with whom they acted in the world } \\
& \text {... So long as the dead are remembered through stories, } \\
& \text { their lives will be significant (2002: 303). }
\end{aligned}
$$

But what are Melibea's deeds to be recounted? What was her way of being in the world? From Pleberio's perspective there is nothing to recount but shame, as he must mourn a young woman whose life and death are far from exemplary. Therefore, Pleberio's narrative must turn to himself in order to create meaning out of Melibea's death. ${ }^{32}$

Understood as a discursive category, grief in Celestina becomes a linguistic construction for characters to try to make sense of death. However, to fully understand the implications of grief as a linguistic discourse in Celestina the role of language in this work needs to be acknowledged. In Rojas' fictional world nothing is real or bears existence until it is com-

31.- This is the case of the other four laments present in Celestina; those of Areúsa, Elicia, and Calisto. These characters' grief for the deaths of Celestina, Pármeno, and Sempronio is sustained by means of a narrative that, as Emilio de Miguel Martínez indicates, Rojas has used to characterize the survivors: «el cálculo interesado de Celestina, el descarnado egoísmo de Calisto, la espontaneidad y llaneza de prostitutas, y finalmente, el radical apasionamiento de Melibea» (2001: 177). The difference with that of Pleberio is that, although in the previous laments there is a tendency towards individuality, this trend does not really take root. The narrative of the aforementioned characters portrays archetypes of survivors and focuses substantially on the deceased. It is with Pleberio's lament that Rojas moves from the archetypical to the individual survivor in detriment of the deceased. For more information about these laments see: Louise M. Haywood (2001), "Models for Mourning and Magic Words in Celestina», BHS, lxxviii, pp. 81-88; Lía Noemí Uriarte Rebaudi (1989), «Los plantos de la Celestina». Actas del Congreso Internacional sobre literatura hispánica en la época de los Reyes Católicos y el descubrimiento, Madrid: Promociones y Publicaciones Universitarias, pp. 304-307; and the works by David G. Pattison (2001) and Emilio de Miguel Martínez (2001) mentioned in the present essay.

32.- In this sense, Emilio de Miguel Martínez notes that the panegiric and the direct consolation are excluded from Pleberio's speech due to the fact that he is lamenting the death of a suicide (2001: 178). On her part Lacarra Lanz also points to this reason to explain why Pleberio's speech qualifies as a lament rather than a planctus. Pleberio's speech, she maintains, «no podría incluir partes esenciales del planto como la etopeya de Melibea comparándola a ilustres mujeres, el loor de la hija o la invocación a Dios para que la acoja en el Paraíso» (Lacarra 2007: 206). 
municated. In Celestina, feelings and events take on existence and significance only when they are mediated through language. In fact, as George Shipley reminds us, Rojas' characters depend, habitually and delusively, "on rhetoric to give satisfying verbal form to ideas rarely (and then only briefly) realized in their objective experience» (1975: 143). These characters, and by extension their feelings, cannot exist outside communication. Let us remember Celestina's own words in this regard: «los bienes, si no son communicados no son bienes» (Act I, 115); "El deleyte es con los amigos en las cosas sensuales, y en especial en recontar las cosas de amores y comunicarlas» (Act I, 126); or those of Pármeno: «el plazer no comunicado no es plazer» (Act VIII, 212). Extrapolating this credo to grief, it would be reasonable to think that grief cannot exist until it is communicated, that is, until it is turned into a discursive process. It is at this juncture where grief intersects with language and crosses with loneliness: you can only be a grieving subject when you communicate your pain to others who in turn recognize you as such which, as we have seen in Pleberio's case, does not happen. Language, then, works together with grief - two concepts that are a form of desire - in order to emphasize Pleberio's protagonism as the survivor of Melibea's death.

Grief's dependence on language in Celestina is directly revealed in one of the most moving moments in Pleberio's final speech when the despairing father exclaims: "¿Qué haré quando entre en tu cámara y retraymiento y la halle sola? ¿Qué haré de que no respondas si te llamo? ¿Quién me podrá cobrir la gran falta que tú me hazes?» (Act XXI, 340). This moment captures how language, grief, and loneliness converge in Pleberio's expression of pain. The component of "searching" for the dead that characterizes grieving is evident, and yet these words serve as a means to highlight the abandonment that Pleberio experiences as a survivor. These questions succeed in illustrating the cause and the conflict of Pleberio's grief: the gap that Melibea's absence has created for her father, on one hand, and the impossible task of readjusting to a world without the deceased. That is, they speak of the paradox embedded in the fact that «as mourning prolongs an attachment to the other it is in explicit tension with any pragmatically conceived notion of possibility» (Spargo 2004: 20). In this way Pleberio's narrative is emphasizing the role of Melibea as catalyst of her father's narrative of grief. The interrogative "Qué haré," however, suggests that Pleberio is changing the direction of his narrative to focus all the attention on himself as a survivor.

These three questions contribute to the dramatic tension created by Rojas by maintaining a delicate balance between the practical and the emotional. On one hand, the nature of these questions is highly pragmatic as illustrated by the use of the interrogative pronouns that opens them. On the other hand, the desperation that inheres in each of these questions along with the lack of a satisfactory answer charges them emotionally. 
The first question ( «Qué haré quando entre en tu cámara y retraymiento y la halle sola?») emphasizes the daily component of Pleberio's suffering. Melibea's bedroom becomes the household space whose emptiness transforms this everyday space into a source of further anguish through, as Frank Casa has noted, "the piercing pain of memory.» "How will the old man defend himself,» Casa wonders, "against the assaults of remembrance when he enters her room! Here the mention of an everyday place, her room, and of a normal action, going to see his daughter, creates a peculiar sense of particularization, of personal experience» (1968: 26). ${ }^{33}$

What is of interest in the second question ("¿Qué haré de que no respondas si te llamo?») is that Rojas is emphasizing the connection between language and grief as experienced by Pleberio. By presenting the lack of correlation between the verbs "llamar» $y$ "responder», language is recreating the feeling of loneliness that Pleberio experiences when he enters Melibea's room, transformed by death into a silenced space. Additionally, Pleberio enacts his grief as a linguistic interaction between deceased and survivor: a dialogical exchange that is imbalanced as Melibea's silence is equated to Pleberio's voice, thus representing the tension between presence and absence, between the surviving "I» and the deceased «she,» between a real pain and the possibility of healing. That is, Rojas views grief as a linguistic emotion as he is establishing a direct link between the therapeutic use of language and the easing of Pleberio's pain. Finally, the third question (“¿Quién me podrá cobrir la gran falta que tú me hazes?») insists on the balance between the emotional and the pragmatic by emphasizing the fact that Pleberio's grief responds to a dynamic between presence and absence, between a suffering «I» and an irreplaceable «she.» From this point of view, this set of questions highlights the relationship between the pragmatic and the emotional, among language, emptiness, and grief illustrated by both the silence typical of the rhetorical question, on one hand, and the silence of the deceased "she» in the second question, on the other.

The very attempt to conjure Melibea's presence through language serves as the most evident manifestation of her perpetual absence: as Pleberio's rhetorical questions pursue his daughter in the attempt to create a presence, he arrives at a place of linguistic and emotional breakdown as he finds nothing but silence, thus simultaneously continuing the silence at the beginning of his speech and anticipating the desolation that he encounters at very end of the lament. Within the context of his narrative of

33.- The image of Melibea's bedroom becomes more poignant when compared to the literary representation of Leriano's deathbed scene in Carcel de amor, by Diego de San Pedro, or el Maestre don Rodrigo in Coplas por la muerte de su padre by Jorge Manrique, which in turn resemble the typical bedroom of the dying as depicted in the Ars Moriendi. Whereas the two former literary references illustrate a room full of family and friends of the deceased, who is at the center of the rituals, the literary representation of Melibea's room emphasizes her absence and thus focuses on the survivor. 
grief, Pleberio's words move in Melibea's direction but the silence of the deceased returns them to the survivor as he is the only possible interlocutor. If words are usually a source of solace, for Pleberio they become the reminder of Melibea's absence, which necessarily highlights his position as a dejected survivor. Pleberio's narrative posits the survivor's role as a victim who cannot recover the dearly departed: grief is no longer about the lost object but about the suffering subject who is unable to come to terms with his own situation.

Melibea's lack of answer to her father's invoking her presence has laid out the tragic connection between language and grief: for Pleberio, words can neither reproduce the real nor the ritual presence of the deceased. As a linguistic process, grief is trapped in its own discursive dynamic because, if as a reaction, it evokes the desire for the one who is lost, it is precisely the absence of the deceased, and not her presence, which keeps this process in perpetual motion. This is the trap of the dynamics of grief, a process fueled by the very failure that inheres in it, a failure «inscribed in every work of mourning [that] reminds us that mourning is the state in which all that is possible has become impossible» (Spargo 2004: 27). ${ }^{34} \mathrm{Be}-$ ing a survivor, then, means coping with the tragedy of the inability to recover the lost object. The perpetual desire that emphasizes Pleberio's suffering and the lack of an interlocutor that highlights his loneliness, along with language's inability to capture the object of this personal account, converge to necessarily situate this disconsolate father as the sole protagonist of his own narrative of grief. Since grief feeds on an empty linguistic and physical space, since language fails to satisfy Pleberio's desire for Melibea's presence, it is the survivor who becomes the subject of his own discourse: since «she» cannot be recovered, the «I» emerges in her place.

"She» and "I» as a unity has been dissolved by Death, which has undone the family bond between father and daughter, thus forcing Pleberio to redefine his relationship with Melibea. ${ }^{35}$ This process reveals another aspect in which language and grief contribute to Pleberio's loneliness. His new «I» exists in function of a "she» that has disappeared, and as a result the relationship between them needs to be reformulated. In terms of other family relations and death, words transform identity: husband to widower, child to orphan, wife to widow. However, it is precisely in

34.- In this regard, R. Clifton Spargo reminds us that «the mourner's sense of impossibility does not merely arise in the difficulty posed to memory by the lapsing significance of the dead, but also positions a subject on the threshold of irremediable failure» (2004: 8).

35.- The family lexicon is an important component of Pleberio's narrative. Throughout his lament, Pleberio insistently uses the words «father," «mother» and «daughter» to refer to himself, his wife Alisa and Melibea. He also establishes comparisons with famous fathers (Act XXI, 339-40), which shifts the attention to his own recently lost role, and he closes his lament by addressing the dead body of his daughter emphasizing his own position as an abandoned father. For more on parental grief in Medieval literature, see: J. Tolmie. and M. J. Toswell, eds. (2009) Laments for the Lost in Medieval Literature. Turnhout: Brepols Publishers. 
the severed connection between father and daughter that language cannot supply a new identity for the survivor. In the context of Celestina, where everything is made of the stuff of language, the characters' verbal addiction is transformed into absolute failure when, at the work's climax, it fails to provide a linguistic label for a grieving father. The Spanish language lacks a word to define the father or the mother who loses a child, which turns the emotional state caused by the death of a child into a linguistic taboo. This vacuum in language is imbued with alterity for Pleberio, situating him as the 'other' as it emphasizes the impossibility of finding a new subject position within the family environment as reordered by Melibea's demise. As Colin Parkes indicates, in order to mourn "the old environment must be given up, the new accepted» in a process that facilitates «the gradual building-up of a fresh identity» (1972: 11; xii). Language, however, becomes both obstacle and a vacuum preventing Pleberio from finding a new identity. Rojas is thus undermining language's role in mourning which, as R. Clifton Spargo reminds us, is

to repair continuity - between the representation and the real, between the indicative realm of action and the symbolic realm of motive, between presence and $a b$ sence. It is often thought that since mourning traces the gaps, asporias, or chasms of language, the real cultural work of literary grief is to mend the rift between language and meaning that develops from the perspective of one who experiences a great loss. (2004: 11)

As a grieving individual, Pleberio needs to negotiate the change brought by Melibea's death to his identity; that is, he needs to recast his position vis-à-vis his daughter from father to that other category for which language lacks a word: he is the "orphan» of both his child and language. There is, then, a mutually-informing relationship between language and grief: language resists defining Pleberio's new identity as created by the gap left by his daughter, a gap that seems to be reinforced by the fact that there is no word for his new subject position as a childless father. Language betrays Pleberio as it allows him to voice his grief, and yet it fails to recognize his new identity, thus evoking a significant aspect of what it means to be a the survivor of a child: coping with the tragedy that inheres in the inability to recover the lost object in addition to having lost identity in connection to the child. For Pleberio grieving Melibea becomes, then, a process that crafts the impossibility of a father to find a new subject position in relation to his daughter. Mourning, then, «must seem aberrant, characterized by nothing so much as its resistance to the cognitive and recuperative structures of identity» (Spargo 2004: 27). 


\section{Grief and Autobiographical Discourse}

Abandoned by both people and language, which fail to recognize him as a survivor, Pleberio turns his expression of grief into a self-centered life-telling process that focuses on himself. The only answer for Pleberio to his desolate state is to father an autobiographical narrative that, told "por triste experiencia» (Act XXI, 338), counteracts erasure and seeks reaffirmation by revisiting his own life. This attitude is certainly characteristic of modernity as in the Renaissance one's own experience was the foundation to organize the relationship between the world and the individual illustrated by "el interés que cunde en la época del Humanismo por las narraciones personales y por el relato de experiencias llevadas a cabo por los contemporáneos» (Maravall 1966: 461).

Death, story-telling, and survival have a long tradition of being intimately united. As a highly individualized and dynamic process governing the human response to loss, grief has long held a role as the catalyst of personal narratives. When a loved one dies, survivors face the prospect of revising their life story in function of the deceased. By contemplating mourning in terms of a personal narrative, survivors find a way to cope with loss by re-forming their story so that the deceased can be integrated into their lives in a new way and adjust their relationships in ways that restore wholeness (Kelly 1995: 242-245). Death pushes survivors to tell stories in order to work through their pain. They become story-tellers and create a narrative that, focused on the deceased, creates the illusion that the departed has not left them completely, that he or she is somehow still alive both in and because of a narrative that feeds on the desire to retain its lost object through language.

In Pleberio's case, however, this creative process is not centered on Melibea but on himself. His personal account consists of an autobiographical counter-narrative initiated by that other master narrative that erases all biographies: Death. Death becomes the facilitator for Pleberio's process of introspection and self-examination. That is, by way of death Pleberio opens a process of reflection, which within the memento mori tradition is not surprising at all as the dominant doctrine constructed the death of others as the impetus for reflection about one's own death. What is surprising, however, is that Pleberio does not reflect upon his own death, nor does he reflect upon Melibea's death either. Instead he looks at himself by evoking his own past transgressions: he reexamines his own life. This autobiographical shift illustrates the climax of Pleberio's expression of grief in which the deceased serves as the catalyst that is displaced as protagonist. Consequently, the survivor becomes the leading role through his personalized narrative of substitution which now has grown completely self-referential. 
The emphasis on the autobiographical «I» is most clearly manifested in the invective against love. Here, where one would expect Pleberio to rail exclusively against love for the irreparable damage inflicted on his daughter, he instead turns the focus towards himself by scripting an autobiographical account:

¡O amor, amor! ¡Que no pensé que tenías fuerça ni poder de matar a tus subjectos! Herida fue de ti mi juventud, por medio de tus brasas passé: ¿Cómo me soltaste, para me dar la paga de la huyda en mi vegez? Bien pensé que de tus lazos me auía librado, quando los quarenta años toqué, quando fui contento con mi conjugal compañera, quando me vi con el fruto que me cortaste el día de oy. No pensé que tomauas en los hijos la vengança de los padres. (Act XXI, 341)

Unable to find support in others, abandoned by language, and completely alone, Pleberio's personal «I» emerges within his narrative of grief further marginalizing the deceased. This shift entails a double movement in connection to mourning. By this strong autobiographical component, Pleberio crafts a narrative that allows him to articulate his suffering from a subject position based neither on detachment nor dissociation but rather on displacement. This self-referential twist in response to Melibea's death suggests that Pleberio's narrative privileges the presence of the «I» who suffers the absence of the deceased "she.» "Absence persists," Roland Barthes notes, "I must endure it. Hence I will manipulate it: transform the distortion of time into oscillation" (1979: 16). That is, the new autobiographical «I» is an «I» split into two voices that emerge from a view of grief as a dual and dynamic process that, in this case, wavers between two subject positions: ${ }^{36}$ that of the loss-oriented «I» of the victimized father who suffers and yearns for his lost child, thus emphasizing his role as collateral victim, and that other of the restoration-oriented «I» of the survivor, an active agent of his own lament, who observes his own suffering and then pulls back in an attempt to define his new identity as he is painfully aware that he needs to continue to exist in spite of his loss. This autobiographical component, however, does not turn Pleberio's expression of grief into an unethical manifestation of selfishness. As R. Clifton Spargo points out, "might not the mourner's wishful revisioning of the past, through which she unrealistically sustains relationship, also signify profoundly as an ethical openness to the other?» (2004: 9). Although the focus is on his own past he presents himself as victim of love which, in a sense, evokes the emotional attachment with his daughter.

36.- In order to shed light on how Pleberio copes with bereavement, I am drawing here from the dual process model proposed by Margaret Stroebe and Henk Schut (1999) «Dual Process Model of Coping with Bereavement», Death Studies, 23.3, pp. 197-224. 
Regret also plays a role in Pleberio's autobiographical account. As he conjures his past transgressions, guilt taints Pleberio's personal expression of grief thus drawing further attention towards himself as survivor rather than to his deceased daughter. In his attack on the world, for example, Pleberio complains about the excessive concern regarding material goods as he indicates his regret for having left his daughter - his most precious possession - unattended. His autobiographical narrative takes on the tone of a personal testimony in which Pleberio seems to acknowledge that he has dedicated his life to serving the World (Act XXI, 338-339). ${ }^{37}$ However, in terms of Pleberio's self examination, the role of guilt in his self-referential narrative rankles him even more when we realize that, as Joseph Snow notes, as early as Act XII Pleberio "comes very close to sensing that something is amiss," which "is the anticipation we have of the heartbreak and desolation Pleberio feels in Act XXI» (1990: 388). ${ }^{38}$ This fact increases individual guilt, and as a result, turns attention towards personal introspection and self-examination in connection to responsibility. Implicit in Pleberio's attitude is the thought that perhaps should he have been more vigilant, Melibea's death would have never have happened, a realization that requires the subject's recognition of himself as a discrete entity. ${ }^{39}$

Grief becomes, then, a narrative for the survivor. If, as Colin Parkes points out, "all societies see death as a transition for the person who dies» (1997: 5), the Pleberic model of grief applies this transitional condition not to the deceased but to the survivor. Pleberio has negotiated the two selves emerging from grief in a frustrated attempt to insert himself into the new emotional cartography delineated by his loss. After all, as John Bowlby indicates, these biopsychosocial transitions "are the times when we reassess our picture of the world and our means of being a part of it. They are experienced as impinging upon us but their effects include major changes in the heartland of the self» (1972: xiii). In this sense, Ple-

37.- In this context the "world" is to be understood as world of created things, and therefore of material goods. See: Otis H. Green (1965), «Did the 'World' 'Create' Pleberio?», Romanische Forschungen, 77, pp. 108-10.

38.- In this sense, it is important to point out that Pleberio's awakening to Melibea's reality is gradual, achieving its climax in Act xx: from the unmarked "¿Qué quieres, Lucrecia?» to the urgent "¿Qué quieres tan presurosa?» to the peevishness contained in «¿Qué pides con tanta importunidad e poco sosiego?» to the final "¿Qué es lo que mi hija ha sentido?» (Shipley 1975: 148).

39.- In terms of this self-awareness, it is interesting to point out that in the 15th century the Church starts using confessionals in order to emphasize the existence of each individual's consciousness. These texts were manuals whose main objective was to instruct priests on the powers of confession and absolution, as well as on the ways to conduct this process. They were also directed towards helping the penitent to examine his/her conscience before the rite was performed. This act of religious responsibility suggests that these texts were used to encourage individuals to stop depending on a community and focus on themselves as autonomous beings. 
berio's narrative of grief illustrates a dialectic of suffering between the surviving «I» and the deceased «she»: Melibea's not «being» is Pleberio's platform «to be.» In this autobiographical account that Pleberio fathers in response to his daughter's death, introspection, self-examination and grief work together to define him as a modern survivo .

\section{The Emergence of a New dignitas hominis in Early Modern Spain}

Within the Spanish Early Modern literary tradition both Pleberio and Rojas emerge as individual voices that threaten the central powers by becoming socially visible. As a consequence they are both considered subversive, and thus marginalized. However, as Barbara Babcock indicates "what is socially peripheral is often symbolically central» (1978: 32). This seems to be the case for both Fernando de Rojas and Pleberio. Rojas is defying both literary tradition and manifesting the new mentality towards death and life that moves from the collective to the individual. In fact, in the context of Pleberio's lament, Rojas seems to be more preoccupied with the life of the living rather than with the life of the dead. Far from blindly adhering to the premises that typically characterize the planctus as consolatory topoi, Pleberio's speech emphasizes preoccupation with personal introspection rather than with finding solace. ${ }^{40}$ Rojas' text seeks to transcend by means of the individual, a shift that catapults Pleberio's lament into modernity as this individualistic sentiment foreshadows "our modern sensibilities and our waning conviction in the cultural truths of religious consolation» (Spargo 2004: 95). ${ }^{41}$ Additionally, the very structure of this lament also informs a more modern attitude as it reproduces the dialectic tension between survivor and deceased privileging the former. From the literary point of view Rojas creates a unique voice that, at

40.- As Luis Miguel Vicente points out «el lamento de Pleberio sólo ha conservado parte de la estructura, en tanto que ha suprimido dos aspectos esenciales de la elegía como son los elogios del difunto y la consolación» (1988: 37). In fact, as Michael Gerli indicates, Pleberio's lament is an unorthodox planctus that breaks away from the norm as «unlike the traditional dirge the moral intoned is not consolatory. Indeed Pleberio's words are an aggressive, negative, and heretical judgment passed upon the World and God» (Gerli 1976: 69). It is this turn from religion to materialism that allows Gerli to view this lament as a "rebellion against the ethos of religious and literary convention. It is an anguished plea for individualism as opposed to the bogus security provided by uncritical conformity to literary traditions and Christian views» (1976: 73).

41.- This lack of interest in consolation is, according to R. Clifton Spargo, a sign of modern times. In the present modernity, he argues, «the elegy takes a turn against itself and begins to doubt the literary conventions for redeeming grief as well as the broader sociophilosophical possibility of consolation» (2004: 131). 
the very end of the $15^{\text {th }}$ Century, bends without breaking the rules of the traditional literary model of Medieval mourning. ${ }^{42}$

This ideological ambivalence qualifies Pleberio's lament as a point of inflection between the expression of medieval pain (formulaic, religious, and collective) and early modern suffering (introspective, secular, and individual). On the very cusp of modernity, this father's personal account of grief functions as an ideological pendulum that oscillates between tradition and innovation, between the medieval and the modern; however, its last arc clearly favors a new attitude towards the survivor's subjectivity, thus anchoring Pleberio's account of grief as a narrative of modernity. In Rojas' hands, this lament serves as a turning point, as a bridge that both unites and separates "antiguos» $y$ "modernos.» " $^{43}$ In this light, Pleberio's expression of pain can, in fact, be qualified as a modern revisionary lament, much in the way in which R. Clifton Spargo defines "revisionary elegy,» which "perceives a gap between the intentions of the tradition (which seeks a resolution of loss and a perpetuation of the social order) and present loss (which by its very irresolution would stand for the value of the other)» (2004: 129). ${ }^{44}$ Through Rojas' literary mastery, Pleberio's expression of grief for Melibea in 1499 represents a textual hinge between the need to find «nuevas maneras» to deal with old topics, just as Iñigo López de Mendoza tells us around 1448 when he writes «penssé investigar alguna nueva manera, asy como remedios, o meditaçión contra Fortuna» (Kerkhof 2003:440), and that «nuevo sentimiento» attributed to Garcilaso de la Vega around the second decade of the 1500s. Pleberio's voice inaugurates modernity, as his expression of grief is dissident enough to open cracks in the rigid structures of medieval mourning, thus paving the way for early modern authors.

Pleberio is highly individualized by means of a narrative of grief in which he figures as the protagonist. In fact, rather than lamenting Me-

42.- Scholary criticism on Celestina has long documented Rojas' success in creating an individual response even while working with traditional elements. For María Rosa Lida de Malkiel «la figura de Pleberio es la refutación del artista moderno al viejo esquema tradicional» (1962: 479). Along these lines, it is important to keep in mind that, as Michael Gerli concludes, "while the Medieval desire to exemplify is very much a part of Fernando de Rojas art, the lesson taught is extraordinarily modern" (1976: 73).

43.- Building on the ideas of José Ortega y Gasset, José Antonio Maravall reminds us that the concept of modernity reveals the consciousness of "una subida del nivel histórico, " a new life that is superior to the old one which allows the modern individual to be "a la altura de los tiempos» (1966: 16-17). In Celestina, the rupture between the old and the new times that entails a new level in history is illustrated by Melibea's failure to articulate «algunas consolatorias palabras te diría antes de mi agradable fin, coligidas y sacadas de aquellos antigos libros que [tú] [Pleberio], por más aclarar mi ingenio, me mandavas leer» (Act xx, 334).

44.- This shift from deceased to survivor provides Pleberio's lament with an anti-elegiac sentiment that projects his narrative of grief towards modernity. See the chapter entitled "How Modern is your Grief?» in which R. Clifton Spargo discusses that we «might argue that elegies are modern to the degree that they are anti-elegiac» (2004: 131). 
libea's death, Pleberio examines his own life. ${ }^{45}$ This father stands alone as one of the first sons of Pre-Renaissance Spain, a nation in the making where Humanism bursts into the philosophical arena advocating for the emergence of an "I» that is above the medieval «we.» From beginning to end, then, Pleberio's lament is a narrative triggered by a third person deceased but oriented towards a first person survivor. The emergence of this individual voice focuses on the survivor who refuses to be a mere collateral victim of death and claims for himself a position of privilege in his narrative of grief. By doing this, paradoxically, Pleberio reaffirms his position as a marginalized subject who, abandoned by his wife, his daughter, language, and God, stands in complete solitude as the sole protagonist of what he views as an absolute loss. ${ }^{46}$

For Pleberio there seems to be no possibility of consolation neither in this world nor in the next as there is no mention of the eternal solace in his lament. ${ }^{47}$ This aspect individualizes him as a unique survivor who turns his back on the $15^{\text {th }}$ Century elegiac tradition that «expressed its grief by giving a perfect consolation to the mourner» (Dunn 1976: 147). Rojas refuses to grant Pleberio any comfort at all because he wants his character to be able to experience «incogitado dolor» (Act XIV, 336); that is, inconceivable pain. Here lies the suggestion that whereas medieval pain could be mediated by structures and patterns, early modern suffering cannot, at least not by applying the old medieval model. If consolation is a sort of emotional movement that goes from a desolate «I,» who suffers temporarily, to a divine "you," who comforts eternally, for Pleberio that movement goes from a suffering «I» who necessarily turns into an abject «I,» to the individual abandoned to his own devices. This absolute isolation is what leads Pleberio to desperately exclaim: « $\mathrm{O}$ lastimado viejo! Que quanto más busco consuelos, menos razón fallo para me consolar» (Act XXI, 340), ${ }^{48}$ thus illustrating the early modern ethos of

45.- According to Michael Gerli this is one way in which Rojas undermines the traditional framework of the planctus topos by applying it to life (1976: 70).

46.- Many critics have seen in this ending the seeds of an existentialist crisis in Fernando de Rojas voiced through his character Pleberio. In fact, as Luis Miguel Vicente points out, with Pleberio's lament we witness «the expression of an anguish that is more existentialist than religious» (1988: 40). Peter Dunn, however, characterizes this godless situation of Pleberio as a «displacement of God as the source of authority and retribution» (1976: 410). Manuel Durán, on his part, sees the final conclusion of Celestina as nihilistic because "los personajes se agitaban, en busca de más vida, y se encuentran de pronto con la muerte» (1960: 70-71). See: Manuel Durán (1960), La ambigüedad en el Quijote, Xalapa, Universidad Veracruzana.

47.- Here lies, according to Luis Miguel Vicente, an important difference between Pleberio's lament and that of the Duchess Coleria and Laureola's mother in Cárcel de amor: «desde la perspectiva de los padres, es que no hay asomo de consolación para Pleberio, mientras que las madres de Laureola y Leriano encuentran consuelo en la trascendencia de la vida eterna» (1988: 36).

48.- As a psychological recourse for obtaining a degree of solace, Pleberio seeks consolation thinking about other grieving fathers but this emotional strategy fails and he feels even 
an anthropocentric vision of the world in contrast to the theocentrism that pervades the medieval universe.

In Celestina, the insistence on the "I» instead of God suggests an antagonism between the divine and the human as in Rojas' text there is no God but the individual. With no higher power to turn to, with no one able to provide consolation, Pleberio's expression of bereavement acquires epic connotations as «the epic mourner,» Bruce Wardropper reminds us, "professes himself to be inconsolable. But it is a personal, rather than a public, inconsolability that is here involved. In the epic there is no display of public mourning, but an expression of the sorrow in an old man's heart» (1964: 143). In this light, Pleberio carves out of the death of his child a personal narrative of grief that concludes by addressing the deceased with this final self-centered statement: "¿Por qué te mostraste tan cruel con tu viejo padre? ¿Por qué me dexaste, quando yo te avía de dexar? ¿Por qué me dexaste penado? ¿Por qué me dexaste triste y solo in hac lacrimarum valle?» (Act XXI, 343). With this address to his dead daughter and her silence as the only possible response, Rojas seems to close the cycle of Pleberio's grief. Melibea's lack of response takes us back to the initial silence that Pleberio endures at the beginning of his speech, thus suggesting that from the very beginning the whole structure of this lament hinted at perpetual dissatisfaction for the survivor. After all, "a mourner's sympathy,» R. Clifton Spargo notes «is opposed by a doubly resistant reality - because other human beings as objects of desire do not cooperate with our wishes in the first place, and because they do so even less once they are dead» (2004: 22).

Pleberio's personal lament thus manifests a key shift in attitudes towards death as it suggests that for this wretched father living alone is to be feared more than death; that is, the living "I» is more important than the deceased «she.» This particular narrative rests on and simultaneously facilitates the discovery of the self, the emergence of a humanistic dignitas hominis. As presented in Celestina, this idea suggests an attempt to resolve the conflict inherent in the manifestation of grief: the tension between the impossible task of recovering the lost object and the ways

more alone (Act xxI, 339-340). As Eukene Lacarra Lanz points out, "la muerte deshonrosa de Melibea es la razón por la que su padre no puede encontrar consuelo. Lo busca entre otros padres cuyos hijos también murieron, pero ninguno lo puede acompañar en su dolor. Otros padres lloran la muerte honorable de sus hijos, él llora la muerte desesperada de su hija» (2007: 205). Peter Dunn, however, suggests that there is evidence of self-consolation in Pleberio's words: «agora perderé contigo, mi desdichada hija, los miedos y temores que cada día me espauorecían: sola tu muerte es la que a mí me haze seguro de sospecha». According to Dunn this sentence can only mean one thing: «that in the midst of pain he feels some relief that he need no longer have jealous fears each day for her honor. There is after all», Dunn continues, "some small profit to be had from her death, in the old man's peace of mind. As his daughter's corpse lies at his feet, he cries out that all his wealth and conspicuous luxury are wasted for lack of an heir» (1976: 416). 
to express the suffering that this failure causes. Fernando de Rojas suggests a reconfiguration of the very concept of mourning as an ethical act that oscillates between «those who are outside (those, for example, who have mourned inadequately) and the mourner who is truly dedicated to the memory of the other she laments» (Spargo 2004: 5).

From this perspective, Pleberio's lament serves as a bridge between the Middle Ages' concern for the collective and the religious, and the modern age's focus on the self. As a forerunner of modern secularism in regards to death and bereavement, in 1499 grief takes on a new value at this historical moment of emerging individualism. Rojas is thus articulating an example of what José Antonio Maravall has called «un humanismo hacia adelante; that is, the kind of humanism represented by authors who, like Fernando de Rojas, refuse to follow old models without questioning them and favors breaking new ground in contrast to those who «no atreviéndose a mirar a la verdad de frente, se reducen a seguir las pisadas de los han ido por delante» (Maravall 1966: 469). ${ }^{49}$ In its novel representation of mourning, Pleberio's lament establishes a decidedly modern approach to grief. By emphasizing the living «I» rather than the deceased «she» Rojas reaffirms the importance of the suffering self as a key element in the construction of the survivor's identity, thus revealing a shift in the literary treatment of mourning. In this sense, Pleberio's narrative of grief embodies a modern notion of the self-constructed by means of the concept of loss, language, and loneliness in the context of death. 


\section{Works Cited}

Ariès, Philippe (1982), The Hour of Our Death. Trans. Helen Weaver. New York, Vintage Books.

BABCOCK, Barbara A. (1978), The Reversible World: Symbolic Inversion In Art And Society. Ithaca, Cornell UP.

BARTHES, Roland (1979), A Lover's Discourse: Fragments. Translated by Richard Howard. New York, Hill and Wang.

BowlBY, John (1972), Foreword. Bereavement: Studies of Grief in Adult Life. By Colin Murray Parkes. New York. International Universities Press.

CASA, Frank P. (1968), «Pleberio's Lament for Melibea», Zeitschrift für Romanische Philologie, 84, pp. 20-29.

Clewell, Tammy (1993), «Mourning Beyond Melancholia: Freud's Psychoanalysis of Loss", Journal of American Psychoanalytic Association, 52.1, pp. 1-25.

DeYermond, Alan D. (1990), «Pleberio's Lost Investment: The Worldly Perspective of Celestina, Act 21", MLN 105.2, pp. 169-179.

DicCionaRIo DE Autoridades, Edición Facsímil, (1969), 3 vols, Madrid, Gredos.

Dunn, Peter N. (1976), «Pleberio's World», Papers of the Modern Language Association, 91, pp. 406-19.

Flightner, James A. (1963), «Pleberio», Hispania, 47, pp. 79-81.

GerLI, Michael (1976), «Pleberio's Lament and Two Literary Topoi: Expositor and Planctus", Romanische Forschungen, 88, pp. 67-74.

Hook, David (1978), “'Para quién edifiqué torres?”: A Footnote to Pleberio's Lament», Forum for Modern Language Studies, 14, pp. 25-31.

Homans, Peter (2000), Symbolic Loss: the Ambiguity of Mourning and Memory at Century's End, Charlottesville: University Press of Virginia.

Kelly, John (1995), "Grief: Re-Forming Life's Story", in The Path Ahead: Readings in Death and Dying, Lynne Ann DeSpelder and Albert Lee Strickland (eds.), McGraw-Hill Companies.

Kerkhof, M.P.A.M. and A. Gómez Moreno, Eds. (2003), Íñigo López de Mendoza Poesías completas, Madrid, Editorial Castalia.

Maravall, José Antonio (1966), Antiguos y modernos. Madrid, Sociedad de Estudios y Publicaciones.

—, (1978), "Interés personal por la casa propia en el Renacimiento", Revue de Littérature Comparée, 52, pp. 255-66.

Martínez, Emilio de Miguel (2001), "Llantos y 'Llanto' en Celestina», in La Celestina: V centenario (1499-1999): Actas del Congreso Internacional, Universidad de Castilla-La Mancha, Ediciones de la Universidad de Castilla-La Mancha, pp. 165-192.

McGowan, John (2002), "What do the Living Owe the Dead?», Southern Humanities Review, 36.4, pp. 301-47. 
Parkes, Colin Murray (1972), Bereavement: Studies of Grief in Adult Life, New York. International Universities Press.

Parkes, Colin Murray, Pittu Laungani, and Bill Young, eds. (1997), Death and Bereavement Across Cultures, in Introduction. London, New York, Routledge, pp. 1-9.

Raphael, Beverley (1983), The Anatomy of Bereavement, New York, Basic Books.

Radcliffe-Brown, A. R. (1964), The Andaman Islanders, New York, Free Press.

Rodríguez Puértolas, Julio (1968), Poesía de protesta en la Edad Media castellana: historia y antología, Madrid, Editorial Gredos.

Sedney, Mary Anne, John E. Baker, and Esther Gross (1994), "The Story's of a Death: Therapeutic Considerations with Bereaved Families", Journal of Marital and Family Therapy, 20.3, pp: 287- 296.

Severin, Dorothy S., ed. (1988), Fernando de Rojas, La Celestina, Madrid, Editorial Cátedra.

Shipley, George A. (1975), “'QQual dolor puede ser tal...?”: A Rhetorical Strategy for Containing Pain in La Celestina», MLN 90.2, pp. 43-153.

SHUCHTER, Stephen and Sidney Zisook (1993), "The Course of Normal Grief.» Handbook of Bereavement. Theory, Research, and Intervention, Margaret Stroebe, Wolfgang Stroebe, and Robert Hansson (eds.), Cambridge, Cambridge UP, pp. 23-43.

Snow, Joseph T. (1990), "Celestina and Pleberio: When Value Systems Collide», en W. C. McDonald and G. R. Mermier (eds.). The Medieval Text. Methods and Hermeneutics. A Volume of Essays in Honor of Edelgard E. DuBruck, Detroit, pp. 381-393.

Spargo, R. Clifton (2004), The Ethics of Mourning: Grief and Responsibility in Elegiac Literature, Baltimore, Johns Hopkins UP.

Strohm, Paul (2000), Theory and the Premodern Text, Minneapolis: University of Minnesota Press.

Varela-Portas de Orduña, Juan (2001), «Amor privado, muerte pública en la Celestina", La Celestina: V Centenario (1499-1999). Actas del Congreso Internacional, Cuenca, pp. 569-579.

WARDropper, Bruce W. (1964), «Pleberio's Lament for Melibea and the Medieval Elegiac Tradition», MLN, 79, pp. 140-52.

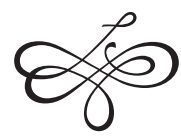




\section{SÁNCHEZ Y SÁnCHEZ, Samuel, «Death Gets Personal: Inventing Early Modern Grief in 15th Century Spain», Celestinesca, 34 (2010), pp. $145-177$.}

\section{RESUMEN}

Este trabajo se centra en el lamento de Pleberio con el objetivo de examinar cómo el dolor de este personaje, tal y como lo articula Rojas, inicia una narrativa personal que surge de una aparente paradoja: la fallecida es el catalizador de este lamento y, a pesar de ello, es desplazada en beneficio de su padre que se convierte en el protagonista de su propia expresión de dolor por la pérdida de su hija. Desde esta perspectiva, el lamento de Pleberio es una narrativa en la que este padre profundiza en su propia experiencia como víctima de la muerte de Melibea en vez de centrarse en la memoria de su hija, lo cual refleja el cambio de una actitud colectiva hacia la muerte a otra mucho más individual e introspectiva. Así mismo, esta expresión de dolor paterno nos ayuda a entender cómo Rojas propone un modelo de luto que no sólo cuestiona las manifestaciones genéricas del lamento sino que además revela un giro conceptual: el dolor medieval se transforma en sufrimiento pre-moderno a través de la reestructuración de la relación tradicional entre el dolor por la muerte de un ser querido, la soledad y el lenguaje.

Palabras Clave: Celestina, dolor, luto, individualidad, lenguaje, soledad.

\section{ABSTRACT}

This essay examines Pleberio's lament for Melibea in order to reflect upon how grief, as conceived by Rojas, initiates a personalized narrative of substitution that entails an apparent paradox: the deceased serves as the catalyst that triggers this response, and yet is displaced as protagonist in favor of the survivor who becomes the center of this exposition of grief. Pleberio's verbal response to his loss takes the form of a narrative that emphasizes the living "I" rather than the deceased "she," thus reflecting a shift from collective to individualized responses to death. Additionally, Pleberio's lament illustrates how Rojas makes sense of death by proposing a model of grief that not only challenges generic manifestations of mourning but also reveals a turn that invokes the metamorphosis of medieval pain into early modern suffering by reformulating the traditional relationship among the bereaved, loneliness, and language.

KEY WORDS: Celestina, grief, mourning, subjectivity, language, loneliness. 